Kaygı, 18(1)/2019: 134-153. Araştırma Makalesi | Research Article

Makale Geliş | Received: 28.12.2018

Makale Kabul | Accepted: 12.01.2019

Yayın Tarihi | Publication Date: 15.03.2019

DOI: $10.20981 /$ kaygi.529805

\author{
Simay İKİER \\ Dr. Öğr. Üyesi | Assist. Prof. Dr. \\ Bahçeşehir Üniversitesi, İktisadi, İdari ve Sosyal Bilimler Fakültesi, İstanbul, TR \\ Bahçeşehir University, Faculty of Economics, Administrative and Social Sciences, İstanbul, TR \\ ORCID: 0000-0003-3810-0958 \\ simay.ikier@eas.bau.edu.tr
}

Nazım GÖKEL

Dr. Öğr. Üyesi | Assist. Prof. Dr. Kilis 7 Aralık Üniversitesi, Fen-Edebiyat Fakültesi, Kilis, TR Kilis 7 Aralık University, Faculty of Arts and Humanities, Kilis, TR

ORCID: 0000-0003-4356-8563 ngokel@yahoo.com

\title{
Bellekte Dilsel Bağlam Bağımlılığı Sorunlarına Düşünce Dili Hipotezi Bir Çözüm Sunabilir Mi?
}

$\ddot{O} \mathbf{z}$

Bilgi bellekte soyutlanmış bir şekilde kodlanıp geri getirilmez. Bağlamıyla birlikte kodlanır ve aynı bağlamın geri getirilme aşamasında da var olması bellek performansını iyileştirir. Bu durum bellekte bağlam bağımlılığı olarak tanımlanmaktadır. Bellek araştırmalarında çevresel, fizyolojik, psikolojik ve dilsel bağlam bağımlılığı etkileri ortaya konulmuştur. Smith ve Vela tarafından 2001 yılında yapılmış olan bir metaanaliz, bellekte çevresel bağlam bağımlılığı etkisini incelemiştir. Metaanalizin hipotezlerinin ardında yatan düşünce, çevresel bağlam bağımlılığı etkisinin, içgörüsel düşünceye yönelmenin söz konusu olduğu durumlarda azalacağıdır. Bu çalışmada, bu düşünce dilsel bağlam bağımlılığına uygulanarak metaanalizin hipotezleri bir kez daha yorumlanmıştır. Dilsel bağlamın çevresel bağlamdan farklı olduğu iddia edilerek hipotezlerin dilsel bağlama uyarlanmasında karşılaşılan sorunlar dile getirilmiştir. Son olarak, Fodor'un Düşünce Dili Hipotezi bu problemleri çözmeye yardımcı olabilecek genel bir düşünsel çerçeve olarak sunulmuş ve bellekte dilsel bağlam bağımlığı için yeni bir açıklama ortaya atılmıştır.

Anahtar Kelimeler: Bellek, Bağlam Bağımlılığı, Dilsel Bağlam, Düşünce Dili Hipotezi.

\section{Can Language of Thought Hypothesis Provide a Solution to the Problems of Lingusitic Context Dependency in Memory?}

\footnotetext{
Abstract

Information is not encoded and retrieved in isolation in memory. It is encoded along with its context, and the presence of the same context at retrieval aids memory performance. This is referred to as context dependency in memory. Environmental, physiological, psychological and linguistic context dependency effects are evident in memory research. A metanalysis was conducted by Smith and Vela in 2001 to investigate the magnitude of environmental context dependency effects in memory. The underlying idea for the hypotheses of the metaanalysis is that in conditions in which one is directed to introspective thought, the magnitude of environmental context dependency effects will be reduced. In the present study, we apply this idea to linguistic
} 


\section{Simay İKİER \& Nazım GÖKEL, "Bellekte Dilsel Bağlam Bağımlılı̆̆ Sorunlarına Düşünce Dili Hipotezi Bir Çözüm Bulabilir Mi” Kaygı, 18(1)/2019: 134-153.}

context dependency, and reconsider the hypotheses of the metaanalysis. We argue that linguistic context is different from environmental context and present the problems in applications of the hypotheses to linguistic context dependency. Eventually, we propose Fodor's Language of Thought Hypothesis as a broader framework which can be helpful in solving these problems and present an alternative explanation for linguistic context dependency in memory.

Keywords: Memory, Context Dependency, Linguistic Context, Language of Thought Hypothesis.

\section{Giriș ${ }^{1}$}

Bellek zihinsel yaşantımızın, daha da genelinde zihinselliğin aslında tanımlayıcı özelliklerinden birisidir. Bir yandan dış dünyaya dair bilgimizin temelinde, diğer bir yandan ise iç dünyamıza, yani benlik, kişisel geçmişimiz ve özdeşliğimize dair bilginin temelinde yer alır. Felsefecilerin özellikle dış dünyanın bilgisinin gerekçelendirilmesi, kişisel özdeşlik ölçütünün belirlenmesi gibi meselelerde bir noktada belleğe başvurduklarını ve kendi genel yaklaşımları neticesinde farklı bellek kuramları ortaya attıklarını görüyoruz. Platon'da hatırlama (Yun. "anamnesis") vasıtasıyla ruh daha önce tanış olduğu ideaları geri getirirken hakiki bilgiye ulaşma imkanına sahip olur (Platon 2012; Platon 2014; Platon 2009); Aristoteles ise De Memoria et Reminiscentia eserinde yaptığı ayrımla aslında tam da çağdaş bilişsel psikologların yaptığ gibi belleğin türlerini ayırt etmeye çalışır (Aristoteles 2007, Annas 1995) ve daha önce De Anima'da çizmiş olduğu genel metafizik çerçeveden ayrılmadan belleği maddesel olan ile ilişkisi içerisinde [aynı bir bilim insanı gibi] inceler. Annas'ın yorumuna göre, Aristoteles De Memoria et Reminiscentia eserinde aslında çağdaş görgül psikolojinin belki de ilk adımlarını atarak bellek (Yun. "mneme") ile hatıllama-geri getirme (Yun. "anamnesis") arasında çok önemli bir ayrım yapar. Bellek sözcüğü ile Aristoteles kişisel belleği kasteder; hatırlama-geri getirme sürecini ise bellekten kişisel-olmaması itibariyle ayırır. Felsefe tarihindeki çeşitli dönemlere baktığımızda diğer felsefecilerin de Aristoteles gibi kişisel belleğe, belleğin diğer türlerine göre daha fazla önem verdiğine ş̧ahit oluyoruz.

\footnotetext{
${ }^{1} \mathrm{Bu}$ makaledeki bütün çeviriler bize aittir. Çeviriler içindeki italik vurgular ise orijinal metinlerin yazarlarına aittir.
} 
Locke'un kuramında, kişisel özdeşliğin yegâne ölçütü psikolojik sürekliliktir ve bunu da sağlayan şey kişinin belleğidir (Locke 2017). Russell'da ise, bellek hem dış dünyanın hem de iç dünyanın bilgisinin tesisinde çok merkezi bir konumda yer alır. Bizim zihnimizin dışında var olan şeyleri ancak zihnimizde o nesnelerin bizde bıraktığı duyu verilerinin veya tümellerin bellekte bir şekilde korunmasıyla bilebiliriz; yine aynı şekilde içgörü (İng., "introspection") vasıtasıyla tanışı olduğumuz düşünce ve duygular gibi iç duyuların bilgisi de bellekte saklanır. Buradan hareketle, Ben'in olası varlığının bilgisini de yine bellek vasitasıyla edindiğimiz söylenebilir (Russell 1911/1994: 42-45). Günümüze baktığımızda ise, artık felsefe içerisinde kendisine ayrı bir yer edinmiş yeni bir disiplin alanından bahsediyoruz: "bellek felsefesi" (Malcolm 1970; Bernecker \& Michaelian 2017; Michaelian \& Sutton 2017).

Bu çalışmada, literatürde çoğunlukla disiplinler arası çalışmalar üzerinden kendi zeminini oluşturan bellek felsefesine, daha da genelinde bilişsel bilimler literatürüne bir katkıda bulunacağımızı düşünüyoruz. Bu çalışmanın ilk bölümünde, Tulving'in bellek için öne sürdüğü Kodlama Özgüllüğü İlkesinin ayrıntılarına değineceğiz. İkinci bölümde, Kodlama Özgüllüğü İlkesini doğal dillere uygulayıp burada ortaya çıkan gerek görgül gerekse kuramsal sorular üzerinde duracağız. Üçüncü bölüm olan tartışma bölümünde ise, aslında psikoloji literatürü içerisindeki deneylerin felsefi çerçevesini oluşturabileceğine inandığımız Fodor'un Düşünce Dili Hipotezi'ne değinecek ve bu kuramsal çerçeve kullanılarak bu araştırma içerisinde karşılaştığımız bir sorunun nasıl çözülebileceğini, bu kuramsal çerçevenin deneyleri yorumlama ve açıklama noktasında nasıl daha verimli bir noktaya işaret ettiğini açıklamaya çalışacağız.

\section{Bellekte Bağlam Bağımlılığı}

Düşünce akışı içinde zihnimizden geçen bilgiler hiçbir zaman soyutlanmış bir biçimde var olmamaktadır. Bilgi her zaman çevresel faktörlerden, kişinin düşünürken kullandığı dilden, kişinin fizyolojik ve psikolojik süreçlerinden etkilenerek ve bu süreçlerle iç içe kodlanır. Bu durum, belleğe kaydedilen ve daha sonra geri getirilen bilgi için de geçerlidir. Bellek izleri de bir bağlam içinde var olan izlerdir. 


\section{Simay İKİER \& Nazım GÖKEL, "Bellekte Dilsel Bağlam Bağımlılı̆̆ Sorunlarına Düşünce Dili Hipotezi Bir Çözüm Bulabilir Mi” Kaygı, 18(1)/2019: 134-153.}

Çocukluğumuzu geçirdiğimiz eve bir gün geri döndüğümüzde, kendimizi çocukluk anılarımızı hatırlarken bulmamızın nedeni, çevresel bağlamın bu anıları geri getirmeye yardımcı olmasidır.

Tulving’in Kodlama Özgüllüğg̈ İlkesi (İng., "Encoding Specificity Principle"; Tulving \& Thomson 1973) bilginin kodlanırken bağlamı ile birlikte kodlandığını ve bu bağlamın geri getirme aşamasında var olmasının bellek performansını iyileştireceğini belirtir. Kodlama Özgüllüğü İlkesi kapsamında bağlam kavramının çeşitli anlamlarda kullanıldığı görgül ve kuramsal çalışmalar süregelmektedir (Smith \& Vela 2001). Bu araştırmalarda sıkça kullanılan deneysel yöntemde, örneğin bir sözcük listesi gibi bir hedef bilgi, öğrenme aşamasında bir bağlamda (Bağlam 1) kodlanıp, test aşamasında ise ya aynı bağlamda (Bağlam 1) ya da farklı bir bağlamda (Bağlam 2) geri getirilmektedir. $\mathrm{Bu}$ deneysel değişimleme, kodlama ve geri getirme aşamasının aynı olduğu iki koşul (Bağlam 1-Bağlam 1; Bağlam 2-Bağlam 2) ve aynı olmadığı iki koşul (Bağlam 1Bağlam 2; Bağlam 2-Bağlam 1) ile sonuçlanmaktadır. ${ }^{2}$ Bağlam bağımlı bellek araştırmalarında bağlam çeşitli şekillerde tanımlanabilir. İlk başlarda yapılan araştırmalarda, farklı deneysel koşullarda öğrenilen bilgiyle ilgili verilen bellek ipuçları veya bilginin kodlama ve geri getirme aşamasında yüzeysel mi yoksa anlamsal $\mathrm{m}$ işlendiği (Tulving \& Thompson 1973) bir bağlam olarak alınmıştır. Daha sonraki çalı̧̧malarda ise çevresel bağlam, fizyolojik bağlam, duygusal bağlam ve bu araştırmanın özellikle üzerinde durmayı amaçladığı dilsel bağlam değişimlenmiştir. Mihenk taşı araştırmalardan örnekler vermek gerekirse, çevresel bağlamın değişimlendiği bir araştırmada, dalgıçlar öğrenme aşamasında verilen bilgiyi suyun altında veya karada edinmiş, test aşamasında bilgiyi ya aynı çevresel bağlamda ya da farklı çevresel bağlamda geri getirmişlerdir. Sonuçlar, öğrenme ve geri getirme aşamalarında var olan bağlamın tutarlı olmasının bellek performansını artırdığını

\footnotetext{
${ }^{2}$ Bu makale boyunca kodlama ve geri getirme aşamasında bağlamların aynı olmasını ifade etmek için "tutarlılık", farklı olduğunu ifade etmek için "tutarsızlı"” terimlerini kullanacağız. Bu anlamda kullandığımız "tutarlılık" terimi ve modern mantıkta geçen "tutarlılık" terimi arasında bir bağlantı yoktur.
} 
göstermektedir (Godden \& Baddeley 1975). Bu etkiye Bă̆lam Bağımlılı̆̆ı Etkisi adı verilmektedir. ${ }^{3}$

Bağlamın bellek üzerindeki etkisi birçok araştırmada güçlü bir şekilde görülürken, başka birtakım araştırmalarda ise etki büyüklüğü daha küçük olarak gözlemlenmekte veya etki ortadan kalkmaktadır. Smith ve Vela (2001) çevresel bağlam ile sınırladıkları analizlerinde, bellekteki bağlam bağımlılığı etkisinin büyüklüğü ile ilgili dört ana hipotez ortaya atmışlardır: Yenileme (İng., "Reinstatement") hipotezi söz konusu araştırmalardaki genel bulguyu vurgulayarak geri getirme aşamasında kodlama aşamasındaki çevresel bağlama yeniden maruz kalındığı durumda bağlam etkisinin artacağını öngörür. Günlük hayatımızda, aklımızdan geçen bir düşünceyi başka bir odaya geçtiğimizde hatırlayamayabilir ve hatırlayabilmek için o düşünceyi düşündüğümüz odaya geri dönebiliriz. Düşüncenin zihinde ilk belirdiği çevresel bağlama geri dönmek o düşüncenin hatırlanmasına yardımcı olur.

Aşağıda bahsedeceğimiz hipotezler ise içgörüsel düşüncenin (İng., "Introspective thought”) bir sonucu olarak bağlam etkisinin azalacağını öngörür. Glenberg (1997) bilginin ve çevresel bağlamın temsil edilmesinin aynı bilişsel kaynakları kullandığını iddia eder. Dolayısıyla çevresel bağlamdan uzaklaşmak (ör. görsel uyaranları dışarıda bırakmak amacıyla gözleri kapatmak), bilişsel kaynakların hedef bilgiye yönelmesine olanak sağlayacaktır. Aynı şekilde içgörüsel düşünce, örneğin, bazı kavramlar üzerine düşünme, bilgileri ilişkisel olarak birbirine bağlama, zihinde canlandırma gibi süreçler

\footnotetext{
${ }^{3}$ Fizyolojik bağlam bağımlılığının incelendiği bir başka araştırmada, katılımcıların öğrenme aşamasında alkol aldığı ve almadığı iki ayrı koşul yaratılmıştır. Test aşamasında katılımcılar bilgiyi yine alkolün etkisi altında veya alkol almadan geri getirmişlerdir. Beklenildiği üzere, hatırlama testindeki en düşük hatalar hem kodlamanın, hem de geri getirmenin alkolsüz gerçekleştiği koşuldadır. Ancak en yüksek hata, hem kodlamanın, hem de geri getirmenin alkollü gerçekleştiği koşulda değil, kodlamanın alkolsüz ve geri getirmenin alkollü gerçekleştiği koşuldadır. Kodlama ve geri getirme fizyolojik bağlamlarının tutarsız olduğu bu koşulda bellek performansı, hem kodlama hem de geri getirme aşamalarının alkolün etkisi altında gerçekleştiği koşula göre daha düşüktür, çünkü tutarlılık, en azından bellekteki bağlam bağımlılığı nedeniyle bir avantaj sağlamaktadır (Goodwin, Powell, Bremer, Hoine \& Stern 1969). Bower, Monteiro \& Gilligan (1978) katılımcılara sözcük listelerini mutlu veya mutsuz duygudurumu içindelerken sunmuştur. Benzer şekilde geri getirme aşamasında benzer duygudurum içinde olmak, bağlam bağımlılığı nedeniyle bellek performansını güçlendirmiştir.
} 
de bilişsel kaynakları kullanarak çevresel bağlamın kodlanmasını ve dolayısı ile bağlam etkisini azaltacaktır.

Daha Çok Parlatma (İng., "Outshining") hipotezi, geri getirme aşamasında kişinin çevresel bağlam dışı bilgilerin işlenmesine yöneltilmesinin bir sonucu olarak bağlam etkisinin azalacağını öngörür. ${ }^{4}$ Laboratuvar ortamında uygulanan bellek testi, katılımcıyı çevresel bağlamdan ziyade, bellek testinin doğasında var olan bilgiye yönlendiriyorsa, yani, geri getirme aşamasında verilen test türü, katılımcının testte verilen bilgiyi dikkatlice ve kavramsal düzeyde işlemesini gerektiriyorsa, ki bu bir içgörüsel düşünce sürecidir, bağlam etkisi azalacaktır. Yani kullanılan bellek testi türüne göre çevresel bağlam etkisinin büyüklüğü değişecektir. Bellek testlerinin türlerine baktığımızda direkt bellek ölçümü için kullanılan testler hatırlama testleri ve tanıma testleri olarak sınıflandırılabilir. Hatırlama testlerinde katılımcıdan verilen bilgiyi yeniden oluşturulması istenir. Örneğin, öğrenme aşamasında verilen sözcük listesinin test aşamasında geri getirilmesi talep edilebilir. Hatıllama testlerinde kullanılan birkaç yöntemden biri serbest hatırlama iken, diğeri ipucu ile hatırlamadır. Serbest hatırlamada katılımcı bilgiyi herhangi bir ipucu olmaksızın geri getirirken, ipucu ile hatıllamada hedef bilginin hatırlanmasını kolaylaştıracak bir ipucu verilir. Örneğin, öğrenme aşamasındaki bilginin (ör. PIRASA) ait olduğu kategori (ör. SEBZELER) veya öğrenme aşamasında verilen sözcük çifti için (ör. KALEM-EKMEK) test aşamasında sözcük çiftinin ilk sözcüğü (ör. KALEM-?) ipucu görevi görebilir. Tanıma testlerinde ise öğrenme aşamasında verilen bilginin, test aşamasında daha önce öğrenilmiş bilgi olarak tanınması istenir. Örneğin, öğrenme aşamasında verilen bir sözcük listesi, test aşamasında öğrenme aşamasında görülmemiş sözcüklerden oluşan bir sözcük listesi ile karışık olarak verilerek, katılımcıdan daha önce gördüğü sözcükleri belirtmesi istenebilir. Daha Çok Parlatma hipotezine göre, ipucu ile hatırlama ve tanıma testlerinde, serbest hatırlama testlerine göre daha az çevresel bağlam etkisi

\footnotetext{
${ }^{4}$ Örneğin, bir öğrencinin ismini hatırlamaya çalışırken, ismin öğrenildiği sınıfta dahi olsak, öğrencinin hangi dersin öğrencisi olduğu, başarılı öğrencilerden biri olup olmadığı gibi içgörüsel düşünce süreçlerinin var olduğu durumlarda çevresel bağlam bize pek de yardımcı olmayacaktır.
} 


\section{Simay İKIER \& Nazım GÖKEL, "Bellekte Dilsel Bağlam Bağımlılığı Sorunlarına Düşünce Dili Hipotezi Bir Çözüm Bulabilir Mi” Kaygı, 18(1)/2019: 134-153.}

beklenmektedir. Bunun nedeni, ipucu ile hatırlama ve tanıma testlerinin katılımcının dikkatini öğrenme ve test aşamasında verilen ek bilgiye yönelterek, çevresel bağlamdan uzaklaştırmasıdır. Serbest hatırlama testlerinde ise bu tür bir içgörüsel düşünceye yönlendirme bulunmamaktadır. Benzer şekilde, öğrenme aşamasında bilgi ilişkisel olarak işlendiyse (sözcükler arasındaki anlam ilişkileri dikkate alındıysa), test aşamasında aynı ilişkisel işleme yeniden hatırlanacağından, kişi çevresel bağlama dikkatini çok da fazla yöneltemeyecek ve bağlam etkisi azalacaktır.

Gölgede Brrakma (İng., "Overshadowing") ise Daha Çok Parlatma hipotezinin öngörülerini kodlama aşaması için öngörür. Yani öğrenme aşamasında çevresel bağlam dışındaki düşüncelere yönelmek, bağlam etkisini azaltacaktır. ${ }^{5}$ Bellek çalışmalarında öğrenme aşamasında ilişkisel işleme yapılırsa bağlam etkisinin azalacağ öngörülmektedir.

Zihinsel Yenileme (İng., "Mental Reinstatement") hipotezi ise zihinde bir bağlamın canlandırılmasının çevresel bağlam etkisini azaltacağı tahmininde bulunur. Şöyle ki, geri getirme aşamasında aynı çevresel bağlamda bulunulsa bile, kişi zihninde başka bir bağlamı canlandırıyorsa, çevresel bağlam etkisi azalacaktır. Zihinde canlandırma da bir nevi içgörüsel düşünce sürecidir. Evimizde öğrendiğimiz bir bilgiyi yine evimizde geri getirmeye çalışırken, zihnimizde bir deniz kıyısı bağlam olarak canlanıyorsa, çevresel bağlam hatırlamayı kolaylaştırmayacaktır. Dolayısı ile tanıma testlerinde zaten doğal olarak öğrenme aşaması zihinde canlandırılacağından hatırlama testlerine göre daha az çevresel bağlam etkisi görülecektir.

Buraya kadar çevresel bağlamın bellek performansı üzerindeki etkilerini Smith ve Vela'nın öne sürdüğü kavramsal çerçeve üzerinden analiz etmeye çalıştık. Bu hipotezler, çevresel bağlama dikkatin yöneltilmesinin veya deneysel koşullara bağl1 olarak içgörüsel düşünceye yöneltilmesinin bellek performansına etkilerini öngörmektedir. Dikkat çevresel bağlama yöneltildiğinde bağlam etkisi artarken,

\footnotetext{
${ }^{5}$ Örneğin, günlük hayatta yeni öğrenilecek olan bir kişi ismi, o kişiyle ilgili diğer bilgiler, kişinin tanıdığ diğer kişiler gibi ilişkisel birtakım işlemeler ile öğreniliyorsa, yine çevresel bağlamın kodlanması azalacaktır.
} 
içgörüsel düşünce süreçleri nedeniyle çevresel bağlama yeteri kadar dikkatin verilemediği durumlarda bağlam etkisi azalmaktadır. Bu noktada aynı soruları dilsel bağlam için sormaktayız. Bilginin edinilmesi ile geri getirilmesi aşamalarında aynı doğal dilin kullanılması bellek performansını olumlu etkiler mi? İçgörüsel düşünceye yöneldiğimiz durumlarda, çevresel bağlamda olduğu gibi, dilsel bağlamın bellek üzerindeki etkisi de azalacak mıdır? Fakat, bir noktada konu dilsel bağlama geldiğinde ele aldığımız sorun çok daha karmaşık bir hal almaktadır. Çevresel bağlam dış dünyanın bir parçası iken, dilsel bağlam zihinsel süreçlerin bir parçası gibi görünmektedir. Doğal dilden bağımsız bir içgörüsel düşünce sürecine girebilmek mümkün müdür?

\section{Bellekte Dilsel Bağlam}

$\mathrm{Bu}$ aşamada dilin bir bağlam olarak çevresel bağlamdan farklı olabileceğini ve izleyen satırlardaki analizle ilgili birkaç noktayı vurgulamak istiyoruz: Birincisi, düşünce, kişinin konuştuğu doğal dil(ler)in dışında, kendi içinde sistemli ve doğal diller ile ilişkili ancak bağımsız bir dilin ürünü olabilir (Fodor 1975). İkincisi, çift dilli bireylerin, çeşitli durumlarda bir doğal dilden diğerine geçiş yapmalarını gerektirecek bir bilişsel süreci kullanmaları gerekmektedir. İlerleyen aşamalarda bu noktalar, ilgili kuramsal çerçeve ve görgül bulgular etrafinda tartı̧ılacaktır. Analizin, bellekte dilsel bağlam bağımlılı̆̆ ile ilgili kuramsal bir çerçeve oluşturmasının yanında yeni birtakım görgül araştırma sorularına zemin hazırlaması da amaçlanmaktadır.

İlk olarak temel hipotez olan Yenileme hipotezini ele alarak dilsel bağlama uyarlanabilirliğini sorgulayalım: Bilginin edinilme aşaması ile geri getirilme aşamasındaki doğal dilin aynı dil olması bir bellek avantajı sağlar mı? Aynı hipotezi en azından bazı bellek türleri açısından dilsel bağlam için de ortaya atabilmek mümkündür. Örneğin, Marian ve Neisser (2000) Rusça ve İngilizce konuşan çift dillilerle yaptıkları çalışmalarında katılımcıların otobiyografik anılarını Rusça veya İngilizce gerçekleştirilen görüşme ortamlarında sorgulamışlardır. Sonuçlar, görüşme Rusça yapıldığında Rusça konuşulurken yaşanan olayların geri getirilme olasılığının, İngilizce yapıldığında ise İngilizce konuşulurken yaşanmış olayları geri getirme olasıllı̆ının, 


\section{Simay İKIER \& Nazım GÖKEL, "Bellekte Dilsel Bağlam Bağımlılı̆ı Sorunlarına Düşünce Dili Hipotezi Bir Çözüm Bulabilir Mi” Kaygı, 18(1)/2019: 134-153.}

diğer dil konuşulurken yaşanan anılara göre daha fazla olduğunu ortaya koymuştur. Yani olay hangi dilde kodlanmışsa, geri getirme aşamasında aynı dilsel bağlamın var olması olaya ait otobiyografik anının geri getirilmesini sağlayan bir ipucu olarak belleği desteklemektedir. Ancak otobiyografik bellek, belli bir zamanda yaşanmış bir olayın anlatıldığı, olayla ilgili duygu ve düşüncelerin de anı ile iç içe geçtiği oldukça tümleyici bir bellek türüdür. Burada hatırlanacak bilgi gerçek hayatta yaşanmış olan olaydır ve geri getirme esnasında bu olay hakkında kavramsal düzeyde düşünülür ve yorumlamalar işin içine girer. Tüm bellek türleri bu düzeyde tümleyici ve kavramsal altyapılı olmayabilir. Buradaki görgül sorulardan biri kodlama ve geri getirme aşamalarındaki dilsel bağlamın tutarlı olmasının her bellek türü için bir avantaj sağlayıp sağlamadı̆̆ıdır. Farklı bir bellek türü olarak örtük belleği ele alabiliriz. Örtük Bellek (İng., "implicit memory"), kişinin istemi dışında edinilmiş bir bilginin yine istemsiz olarak geri getirildiği bellek türüdür. Bu bellek türü, dolaylı bellek testleri (İng., "indirect memory tests") ile ölçülür. Dolaylı bellek testlerinde katılımcının öğrenme aşamasında maruz bırakıldığı bilgi, test aşamasında otomatik olarak ortaya çıkar. Örneğin, öğrenme aşamasında verilen sözcük listesindeki sözcüklerin sadece sesli harflerini sayan katılımc1, aynı zamanda bu sözcüklere maruz kalmış olur ve otomatik bir öğrenme gerçekleşir. Test aşamasında katılımcıdan, öğrenme aşamasında verilen sözcüklere ait sözcük parçalarını aklına gelen ilk sözcük ile tamamlaması istendiğinde, söylenen sözcüğün öğrenme aşamasındaki sözcük olma olasıllğı, bu sözcüklere hiç maruz kalınmadığı duruma göre artmaktadır. Bu etki en genel tanımı ile hazır olma etkisidir (İng., "priming effect"). Hazır olma etkisinde önceki deneyimler, sonraki davranış1 etkilemektedir. Hazır olma etkisi tek dilli çalışmalarda kendini gösterebildiği gibi, çift dillilerle yapılan diller arası hazır olma çalışmalarında da gözlenmektedir. Diller arası hazır olma araştırmalarında, çift dillilere bilgi bir dilde verildiğinde diğer dilde yapılan dolaylı bellek testinde kazanımlar ortaya çıkar. Yani bir dilde verilen bilgi diğer dile aktarılarak bir hazır olma etkisi oluşturur (Hernandez \& Reyes 2002). Diller arası hazır olma çalışmaları genelde kontrollü sözcük listelerini içerirler. Bu sözcük listelerinde sözcüklerin dildeki sıklığı, soyutluğu somutluğu ve her iki dilde de benzer sesler içerip 
içermediği gibi özellikleri kontrol edilerek eşitlenir veya sistemli bir biçimde manipüle edilir. Diller arası hazır olma paradigmalarına bir örnek verecek olursak, Türkçede verilen bir sözcük (ör. ELMA) için İngilizcede aynı anlama gelen sözcük ile tamamlanabilecek (ör. APPLE) bir sözcük parçası verilerek (ör. A_ PL_ ), katılımcıya bir dolaylı bellek testi uygulanabilir ve katılımcıdan sözcük parçasını tamamlayan aklına gelen ilk sözcügü söylemesi istenebilir. Bu tür paradigmalarda, diller arası hazır olma etkisi şu şekilde ortaya konulmaktadır: ELMA sözcüğüne maruz kalan kişilerin A _ PL _ sözcük parçasina APPLE sözcüğü ile yanıt verme olasılı̆̆ bu sözcüğe maruz kalmayan kişilere göre daha fazla olacaktır. Bu etki kendini yanıt verme süresinin kısalması ile de gösterebilir. Hazır olma paradigmaları, kontrollü deneysel yapıları ve malzemeleri gereği otobiyografik anı araştırmalarından yapı olarak farklıdır. Buna rağmen, bulgular bir bağlam etkisi olduğuna işaret etmektedir: Öğrenme ve geri getirme aşamalarında doğal dilin aynı olduğu tek dilli hazır olma paradigmalarında elde edilen hazır olma etkisi, aynı olmadığı diller arası hazır olma paradigmasından elde edilen etkiye göre daha güçlü bir etkidir (Travis, Cacoullos \& Kidd 2017). Yenileme hipotezinin tüm bellek türleri için geçerli olup olmayacağı görgül bir sorudur.

Daha Çok Parlatma ve Gölgede Bırakma hipoteleri ise sırasiyla geri getirme ve edinme aşamalarında içgörüsel düşünceye sevk edecek kavramsal, ilişkisel işleme gibi süreçlerin var olduğu durumlarda bağlam etkisinin azalacağını öngörür. Benzer hipotezler dilsel bağlam için de kurulabilir. Kullanılan testin içgörüsel düşünceye sevk etme özelliği, öğrenme ve test aşamaları arasındaki dilsel bağlam tutarlılığının ne ölçüde bellek performansını destekleyeceğini belirleyecektir. Örneğin ipucu ile hatırlama testlerinde, verilen ipucunun değerlendirilmesi kişiyi içgörüsel düşünceye sevkedeceğinden, edinim ve geri getirme aşamalarında doğal dilin aynı olup olmaması serbest hatırlama testlerinde olduğu kadar etkili olmayacaktır. Bunu bir örnekle açıklamak gerekirse, serbest hatıllama ve ipucu ile hatırlama testlerinin kullanıldığı iki ayrı dilsel bağlam deneyi düşünelim. Serbest hatırlama deneyinde, bir doğal dilde verilen sözcük listesi, yine aynı doğal dilde veya farklı bir doğal dilde sorgulanabilir. Sözcük listesi aynı doğal dilde sorgulandığında kişi muhtemelen sözcükleri daha iyi 


\section{Simay İKIER \& Nazım GÖKEL, "Bellekte Dilsel Bağlam Bağımlılı̆ı Sorunlarına Düşünce Dili Hipotezi Bir Çözüm Bulabilir Mi” Kaygı, 18(1)/2019: 134-153.}

hatırlayacaktır çünkü test aşamasında başka herhangi bir ipucu bulunmamaktadır ve hatırlamayı sözcük yapısı, fonolojisi gibi özellikler tetikleyecektir. İpucu ile hatırlama testinde ise PENCERE-KAPI sözcük çifti verildiğinde hangi sözcüğün hangi sözcükle eşlendiğine dair ek bir bilgi kodlanmaktadır. İlk sözcük, ikinci sözcükle bağdaştırılır ve ikinci sözcüğün geri getirilmesindeki en önemli etken bu bağ olacaktır. Test aşamasında WINDOW sözcügü ipucu olarak verildiğinde diğer dildeki sözcüğe (PENCERE) bir geçiş yapılması gerekecek olsa da yanıtın bulunması serbest hatırlamada olduğu kadar dilsel bağlamdan etkilenmeyebilir ve dilsel bağlam etkisi daha küçük olabilir. Çünkü iki sözcük arasındaki anlamsal bağı hatırlamak bir içgörüsel düşünce süreci içerir ve dilsel bağlamın etkisi azalır. Glenberg'in (1997) çevresel bağlam için ileri sürdüğü gibi, eğer içgörüsel bir düşünce süreci söz konusuysa, edinim ve geri getirme aşamalarındaki dilsel bağlamın tutarlı ya da tutarsız olması çok da etkili olmayacaktır. Bu hipotez, daha sonraki araştırmalarda test edilebilecek görgül bir hipotezdir. $\mathrm{Bu}$ hipotezi kurarken varsayımımız içgörüsel düşüncenin doğal dilden bağımsız olarak işlediğidir. İçgörüsel düşünce doğal dilden bağımsız bir şekilde işliyorsa, edinim ve geri getirme aşamaları arasındaki doğal dilin aynı olup olmamasının etkisi azalacaktır. Tıpkı içgörüsel düşünce süreçlerinin çevresel bağlam etkisini azaltacağı gibi. İçgörüsel düşüncenin doğal dilden bağımsız bir süreç olmadığını varsayalım. Bu durumda içgörüsel düşüncenin hangi doğal dilde gerçekleştiği bellek performansını etkileyecektir. Örneğin, PENCEREKAPI arasındaki bağ Türkçe doğal dili ile işleyen bir içgörüsel düşünce sürecine tabi olduğunda test aşamasındaki doğal dilin yanında içgörüsel düşünce sürecinin doğal dilinin ne olduğu da dikkate alınacak mıdır? Bu noktada dilsel bağlam etkisi ile ilgili olarak, içgörüsel düşüncenin bir doğal dilde mi yoksa doğal dilden bağımsız olarak mı gerçekleştiğinin varsayılacağı bir sorun olarak karşımıza çıkmaktadır.

Aynı sorun, başka bir çevresel bağlamın zihinde canlandırılmasının bağlam etkisini azaltacağını öngören Zihinde Canlandırma hipotezinin dilsel bağlama uyarlanmasındaki beklentimiz için de geçerlidir. Anadili Türkçe olan bir akademisyen, Türkçe yapılmış bir bilimsel çalışmayı, uluslararası bir konferansta İngilizce olarak aktaracaksa, edinim ve geri getirme arasındaki dilsel bağlam farklılığına rağmen 
çalışmanın ayrıntılarını zihninde bir içgörüsel düşünce süreci olarak canlandırarak bilgiyi geri getirebilir İngilizce doğal dilinde aktarabilir. Bu durumda geri getirme aşamasındaki dilsel bağlamın edinim aşamasından farklı olması bir sorun yaratmayacaktır. Ancak burada yine zihinde canlandırma sürecinin doğal dilden bağımsız bir süreç olduğunu varsaymak zorundayız.

Çevresel bağlamla ilgili öne sürülen hipotezlerin dilsel bağlama uyarlanması esnasında kurulan hipotezler, dilsel bağlamın çevresel bağlamdan farklı olabileceğine işaret etmektedir. Bu noktada görgül hipotezleri kurabilmek için dille ilgili daha geniş bir düşünsel çerçeveye ihtiyaç vardır. Bu düşünsel çerçeve Fodor (1975) tarafindan düşüncenin doğal dilden bağımsız olarak işleyebileceğinin anlatıldığı Düşünce Dili Hipotezi’nde ortaya atılmaktadır. Bu hipotez, çift dillilerin doğal diller arasında yaptıkları geçiş sürecinin dikkate alınmasına, dilsel bağlam etkisinin büyüklüğü ile ilgili hipotezlerin varsayımlarının kurulmasına ve var olan bulguların başka bir bakış açısıyla yorumlanmasına olanak sağlamaktadır.

\section{Tartışma: Düşünce Dili Hipotezi’nin Getirdiği Çözümler}

Fodor'a (1975: 27) göre, o zamana kadarki psikolojik modellere baktığımızda bu modellerin bilişsel süreçleri berimsel (İng. "computational”) olarak ele aldıkları ortadadır ve berim (İng. "computation") üzerinde berimlemenin gerçekleşeceği bir temsil sistemini gerektirir. Bu noktada, Fodor üç bilişsel görüngüye odaklanır: karar verme, kavram öğrenme ve algı. Bu üç görüngünün detaylı analizinde ise hep aynı sonuç vardır: herhangi bir eylemde bulunmadan önceki karar aşamasında, herhangi bir kavram öğrenme aşamasında ve herhangi bir algı sürecinde bu süreçler ile "rasyonel" davranıştaki yansımaları arasındaki bağlantı ancak bu süreçlerin öncelikle berimsel süreçler olduğunun hakkının verilmesiyle mümkündür (1975: 28-51). Bütün bu bulgulardan hareketle, Fodor bu bulguların berimsel süreçlerin içerisinde gerçekleştiği 
temsil sistemi olan içsel bir Düşünce Dili'ne (İng., "Language of Thought") ${ }^{6}$ işaret ettiğini savunur. ${ }^{7}$ Eğer bütün psikolojik modeller buna işaret ediyorsa, bu Düşünce Dili'nin neye benzediğini incelemek ve ayrıntılarını belirlemek durumundayız (1975: $51-52)^{8}$

Düşünce Dili, diğer adıyla Zihince veya Düşünce, doğal diller ile karşılaştırıldığında özeldir ve içseldir. Birçok kişi, bir dil konuşmaya başladıktan bu yana geliştirdiğimiz alışkanlıklara, peşin hükümlü yargılara (İng., "pre-reflective judgment”), vs., bağlı olarak şu tarzda bir akıl yürütmeyi benimseyebilir: Çocukluğumuzdan beri Türkçe konuşmamız neticesinde Türkçenin "bize göre" düşünce dili olduğunu; aynı şekilde çocukluğundan bu yana İngilizce konuşan birisi de "ona göre” düşünce dilinin İngilizce olduğunu pekâlâ düşünebilir. "Konuşulan doğal dil aynı zamanda düşünce dilidir” tezini savunma eğiliminde olabiliriz (Fodor 1975: 56). Bu tez birçok felsefeci ve psikoloğa çok çekici gelebilir; sonuçta bilişsel süreçlerin berimsel süreçler olduğu ve aynı zamanda bu berimsel süreçlerin bir temsil sistemi gerektirdiği pekâlâ doğru olabilir; ama elimizde doğal diller gibi düşüncenin içinde gerçekleşeceği kamusal-gizemsiz temsil sistemleri varken neden özel-içsel-gizemli bir dili ontolojimize dahil edelim ki? "Tek yapmamız gereken bilişsel süreçlerin üzerinden tanımlandığı

\footnotetext{
${ }^{6}$ Literatürde bu düşünce aslında aynı anlama gelen iki terim ile karşılanıyor. Birincisi, az önce işaret ettiğimiz "Düşünce Dili" terimi, diğeri ise "Zihince" terimi (İng. "Mentalese"). Burada, Türkçe felsefe terminolojisine de bir katkı yapmak için bu "Zihince" terimi yerine "Düşünce" terimini kullanmak daha akılcı bir yaklaşım olabilir. "Düşünce" terimini iki anlamda kullanabiliriz. İlk anlamda düşünce, bilinen anlamıyla inanma, arzu etme, hayal etme, vs., düşünsel faaliyetler olarak ele alınabilir. İkinci anlamda düşün-ce ise (İngilizce, Türkçe kelimelerindekine benzer bir kullanım ile], tam da Fodor'un işaret ettiği düşüncenin içerisinde gerçekleștiği özel-içsel dil anlamında kullanılabilir. Böylelikle, düşünsel faaliyetler ve düşünsel faaliyetlerin içerisinde gerçekleştiği dil arasındaki zorunlu bağlantı tek bir sözcükle vurgulanmış olur.

${ }^{7}$ Bilişsel bilimde daha sonra çıkan Bağlantıcılık (İng., "Connectionist”) akımına göre, bilişsel süreçler her ne kadar berimsel süreçler olsa da bu berimsel süreçlerin kendilerini Fodor'un (1975) iddia ettiği gibi bir dilsel yapı üzerinden gerçekleştirmeye ihtiyacı yoktur. Fodor ve Pylyshyn (1988) ise düşüncenin sistematikliği, üretkenliği ve çıkarımsal tutarlılığı gibi genel özelliklerinin ancak kombinasyonel sentaktik ve semantik yapılarda, daha genel ifadeyle dilsel bir yapıda gerçekleşebileceği iddiasından hareketle Düşünce Dili'ne dair yeni argümanlar geliştirmişlerdir. Bu argümanlara genel bir eleştiri için bkz. Antony (1991).

${ }^{8} \mathrm{Bu}$ makalede bu ayrıntıların sadece bizim uğraştı̆ı̆ımız konuya dair kısımlarını açıklamanın uygun olacağını düşündük. Bütün ayrıntılar için bkz. Fodor (1975).

${ }^{9}$ Fodor'un Wittgenstein'ın özel dilin imkansızlığına dair öne sürdüğü argümanların eleştirisi için $b k z$. Fodor (1975: 65-79).
} 


\section{Simay İKIER \& Nazım GÖKEL, "Bellekte Dilsel Bağlam Bağımlılı̆ı Sorunlarına Düşünce Dili Hipotezi Bir Çözüm Bulabilir Mi” Kaygı, 18(1)/2019: 134-153.}

dilsel nesnelerin kamusal dillerden birisinden elde edilmiş olduğunu varsaymaktır" (Fodor 1975:56).

Fodor'a göre bu öneriyi ciddiye almak mümkün bile değildir. Doğal dillerin düşünce aracı olduğu tezinin en açık reddiyesinin görgül (İng. "empirical”) kanıtını dilsel olmayan ama yine de düşünen organizmalarda buluruz. Daha önce bahsi geçen planlı eylem, kavram öğrenme ve algısal entegrasyon gibi bilinen başarılar dil-öncesi çocukların (İng., "preverbal children") ve evrimsel gelişim itibariyle insanlarla aynı grupta yer alan organizmaların (İng., "infrahuman organisms") yetileri ile de gerçekleşebilir. Bu noktada bir yol ayrımına gireriz: ya bu türden canlıların bilişsel başarılarını surf bir doğal dil konuşmuyorlar diye reddedeceğiz ya da düşüncenin bir doğal dil vasıtasıyla sadece dile getirildiğini, ancak düşüncenin kendisinin Düşünce Dili, diğer adıyla Zihince/Düşünce içerisinde gerçekleştiğini kabul edeceğiz. İlk seçenekte bütün bilimsel bulgular aksini göstereceği için, aslında hem felsefi açıdan hem de bilimsel açıdan makul olan diğer seçeneği doğru olarak kabul etmek durumundayı (Fodor 1975: 56). O halde, bu noktada bir ayrımda bulunmamız gerekiyor: (i) (Düşüncelerimizi bir doğal dil aracılığıyla) dile getirmek/ifade etmek ve (ii) [genel anlamıyla] düşünmek aynı şey olamaz. Bu açıdan bakıldığında, Fodor’un Düşünce Dili Hipotezi'nin bizlerin sıkça düşebileceği bir hatadan kurtardığ söylenebilir. Doğal diller düşünce dili değildir; doğal diller düşüncemizi nasıl ifade edeceğimizi gösteren ifade ediş biçimlerinin bir yekününden ibaret olabilir.

Düşünce Dilini sadece doğal dil konuşan yetişkin insanlarla sınırlamamak, her zihin sahibi varlığın (bağlı bulunduğu berimsel-işlevsel mimariye uygun olarak) içsel olarak sahip olduğu bir temsil sistemi olarak görmenin birtakım kuramsal faydalarından da bahsetmek pekâlâ mümkündür, örneğin ilk (doğal) dilimizi öğrenmeyi açıklaması gibi. Bu noktada, Fodor'un bu konudaki argümanını basitleştirmeler yaparak kısaca sunmak faydalı olacaktır. Diyelim ki İngilizce, Rusça, Çince gibi yeni bir doğal dil öğrenmek istiyoruz. Fakat, bu doğal dili öğrenebilmek için o dilin kavramsal imkanlarına, karmaşıklığına ve semantik zenginliğine en azından eşit ölçüde sahip olan 
başka bir dile sahip olmamız zorunludur. Fodor'un verdiği örnek üzerinden bu noktayı açıklayalım. Formel mantık sisteminde biz ağırlıklı olarak iki formel dil üzerinde uğraşırız: önermesel mantık dili ve niceleme mantığı dili. Bir makineye önermesel mantık dilinin ana öğelerini oluşturan önerme sembolleri, oluşturma kuralları, aksiyomlar ve çıkarım kurallarını yükleyebilir ve önermesel mantık dili içerisindeki bazı teoremlerin kanıtlamasını sağlatabiliriz. Fakat, hiçbir şekilde bu makine niceleme mantığı dilindeki teoremlerin kanıtlamasını sağlayamayacaktır; çünkü niceleme mantık dili önermesel mantık diline göre semantik açıdan daha zengin ve güçlü bir dildir. Önermesel mantık dilindeki bütün teoremler aynı zamanda niceleme mantık dilinin de teoremleridir; fakat tersi geçerli değildir. Önermesel mantık dili yazılımı kullanan bir makinenin kendi kısıtlı semantik kaynaklarını kullanarak görece daha zengin bir dildeki teoremleri bırakın kanttlayabilmesi, o dil içerisinde geçen bazı ifadeleri temsil edebilmesi bile mümkün değildir (Fodor 1975: 93). ${ }^{10}$ Durum böyleyken, önermesel mantık dili yazılımının yüklendiği makineden niceleme mantığını öğrenmesinin beklenmesi de ancak hayal kurmak olur. Buradan hareketle, bir genelleme yapilabilir: Herhangi bir organizmanin yeni bir dili öğrenmesi ancak ve ancak o dil ile en azından eşit ölçüde kavramsal imkanlara sahip olan başka bir dile sahip olmasıyla mümkündür. İkinci bir (doğal) dili öğrenirken daha önceden sahip olduğumuz birinci (doğal) dilin imkanlarını kullanırız. Birinci (doğal) dilimizi de öğrenirken aslında daha önceden sahip olduğumuz başka bir dilin, yani Düşünce Dilinin imkanlarını kullanıyor olmalıyız (Fodor 1975: 58-59). Düşünce dili ise öğrenilen bir dil değildir; düşünce dili doğuştan yaşamımıza dahil olan, diğer dillerin önemli parçası olan toplumsal-sosyal uzlaşımlardan bağımsız, içsel bir koddur (İng. "inner code”). Eğer Düşünce Diline sahip

${ }^{10}$ Basit bir örnek üzerinden giderek bu konuyu şöyle ele alabiliriz: Sezgisel olarak geçerli olduğunu bildiğimiz bir argümana bakalım. Mesela, "bütün insanlar ölümlüdür; Sokrates bir insandır, o halde Sokrates ölümlüdür" argümanının sezgisel olarak geçerli olduğunu biliriz; fakat bu argümanın geçerli olduğunun kanıtlamasını önermesel mantık dili içerisinde yapmamız mümkün olmayacaktı;; çünkü bu türden argümanların geçerliliği veya geçersizliği önermelerin içerisinde geçen "bütün" ve "bazı" gibi kelimelerin anlamlarına bağlıdır (Kalish, Montague \& Mar 1980: 117). Önermesel mantık dilinin kendi kavramsal çerçevesi içerisinde bu ifadeler temsil edilemez ve zaten de temsil edilemediği için o formel dil içerisinde geçerlilikleri de denetlenemez. Bu ancak önermesel mantık dilinden daha zengin olan niceleme mantık dili içerisinde yapılabilir. 
olmasaydık hiçbir doğal dili de öğrenemezdik (Fodor 1975: 64). Bütün insanlarda biyolojik bir sabit gibi düşünülmesi gereken Düşünce Dili'nin evrensel kavramsal zenginliği sayesinde insanlar İngilizceyi, Türkçeyi veya diğer dilleri konuşmayı öğrenerek kendi zihinlerindeki düşünceleri ifade etme şansına sahip olmuşlardır.

Buraya kadar Fodor'un Düşünce Dili Hipotezi'ni ana hatlarıyla özetlemeye çalıştık. Şu üç nokta özellikle daha sonra söyleyeceklerimizle bağlantılı olacağ için esasi bir öneme sahiptir: (i) Bilişsel süreçler esas itibariyle berimsel süreçlerdir ve berimsel süreçler bir temsil sistemini, yani Düşünce Dilini gerektirir; (ii) Bir düşünceyi (herhangi bir doğal dil vasıtasıyla) dile getirmek ile (genel anlamıyla) Düşünce Dilinin içerisinde düşünmek aynı şeyler değildir; (iii) Düşünce Dili sayesinde doğal diller öğrenebilir ve Düşünce Dili içerisindeki düşündüğümüz fikirleri bu öğrendiğimiz doğal diller vasitasiyla dile getirebiliriz.

Önceki bölümde dilsel bağlam için söylediklerimizin şimdi ana hatlarıla sunduğumuz Düşünce Dili Hipotezi çerçevesinde açıklanabileceğini iddia ediyoruz. Vurgulamak istediğimiz iki nokta bulunmaktadır. Birincisi, doğal diller üzerinden konuştuğumuzda, eğer hedef bilgi bir doğal dilde kodlanmışsa, aynı dilsel bağlamın geri getirme aşamasında da var olması bellek performansını iyileştirecektir. Şimdi, Düşünce Dili Hipotezi çerçevesinde meseleyi ele aldığımızda, şu iddiada bulunmalıyız: herhangi birisi ikinci bir dili öğrendiğinde aslında Düşünce Dilinde herhangi bir değişiklik olmayacaktır, Düşünce Dili sabit kalacaktır. Tabi ki yeni bir doğal dil öğrendiğimizdeki deneyimler zaten sahip olduğumuz içsel dilin, yani Düşünce Dilinin daha öncesinde kullanılmayan bazı derin kavramsal kaynaklarını keşfetmemize neden olabilir; fakat bu içten sahip olduğumuz Düşünce Dilinin değiştiğini göstermez, sadece daha öncesinde kullanılmayan bazı öğelerin fark edilmesini sağladığını gösterebilir (Fodor 1975: 8586). İkinci bir doğal dil, bu açıdan bakıldığında, aslında Düşünce Dili içerisindeki düşünceleri dile getirmeye yarayan bir araçtan ibarettir. Dolayısıyla, ikinci doğal dili öğrenen kişi sadece o anda aklından geçen veya bir süredir aklından geçen düşünceleri dile getirmenin yeni bir yolunu öğrenmiştir. 


\section{Simay İKIER \& Nazım GÖKEL, "Bellekte Dilsel Bağlam Bağımlılığı Sorunlarına Düşünce Dili Hipotezi Bir Çözüm Bulabilir Mi” Kaygı, 18(1)/2019: 134-153.}

Bununla bağlantılı olarak içgörüsel düşünce de aslında doğal dillerden bağımsız işleyen bir mekanizmadır. Bir önceki bölümde, çevresel bağlam hipotezlerinin dilsel bağlam için de geçerli olup olmayacağına karar verebilmek için, içgörüsel düşünceyi doğal dil ile işleyen bir süreç olarak kabul edip etmeyeceğimize karar vermemiz gerektiğini vurgulamıştık. Çevresel bağlam için geçerli hipotezlerin, dilsel bağlam için de geçerli olabilmesi için içgörüsel düşüncenin doğal dillerden bağımsız olarak işleyen bir süreç olduğunu varsaymak gerektiğini belirtmiştik. Fodor'un (1975) Düşünce Dili Hipotezi kapsamında, içgörüsel düşünce doğal dillerden bağımsız bir süreç olarak ele alınabileceğinden, bu bakış açısı ile çevresel bağlam için kurulan hipotezler dilsel bağlam için de geçerlidir. İçgörüsel düşünceye yönelmek dilsel bağlam bağımlıllğı etkisinin azaltacaktır.

Vurgulamak istediğimiz ikinci nokta ise şudur: Bellekte bağlam bağımlllı̆̆ araştırmaları, kodlama ve geri getirme bağlamları arasındaki tutarlılı̆̆ı bellek performansını nasıl iyileştirdiği konusunda şöyle bir mekanizmayı vurgular. Öğrenilen bilgi bağlamla beraber kodlanır ve daha sonra aynı bağlamın geri getirme aşamasında var olması, bağlamın bir bellek ipucu görevi görmesini ve bellek performansının iyileşmesini sağlar. $\mathrm{Bu}$ mekanizmanın dilsel bağlam için de aynı şekilde işlediği düşünülmektedir. $\mathrm{Bu}$ mekanizma öğrenme ve geri getirme aşamalarındaki bilgiyi ve bellek ipuçlarını vurgularken, iki aşama arasında nasıl bir sürecin gerçekleştiği konusunda bir şey söylememektedir. Bu iki aşama arasında bir geçiş mekanizmasının (İng., "switching") işlediğini iddia ediyoruz. Şöyle ki, öğrenme ve geri getirme aşamalarında bağlam tutarlı iken kullanılan doğal diller arasında bir geçiş gerekmezken, farklı olduğu durumda kişinin bir doğal dilden diğerine geçiş yapması gerekmektedir. $\mathrm{Bu}$ tür geçiş görevleri yönetimsel görevlerdendir (İng., "executive functions") ve bilişsel bir kaynağın bu geçişe aktarılmasını zorunlu kılar (Banich 2009). Dolayısıyla, dilsel bağlamın kodlama ve geri getirme aşamalarında tutarlı olmaması, kişiye bilişsel olarak ek bir yük, bilişsel bir kontrol mekanizması uygulama zorunluluğu getirecektir. Başlı başına bu bile bellek performansının düşmesine neden olan bir faktör olabilir. 


\section{Sonuç}

Fodor'un (1975) Düşünce Dili Hipotezi hem bellek performansında dilsel bağlamın bağımlılığı etkisini farklı şekilde yorumlamayı sağlarken, hem de sonraki görgül çalışmaların hipotezlerinin varsayımlarının kurulmasına bir temel hazırlamaktadır. Bağlam bağımlılı̆̆ı etkisinin açıklanmasında üzerinde durulmayan edinim ve geri getirme aşamaları arasındaki geçiş mekanizması ve içgörüsel düşünce süreçlerinin doğal dilden bağımsız olarak varsayılabilmesi bu düşünsel çerçeve sayesinde gerçekleşmektedir. 


\section{KAYNAKÇA}

ANNAS, Julia (1997). "Aristotle on Memory and the Self", Essays on Aristotle's De Anima, ed. Martha Craven Nussbaum \& Amélie Rorty, pp. 297-311, Oxford: Clarendon Press.

ANTONY, V. Michael (1991). "Fodor and Pylyshyn on Connectionism", Minds and Machines, 1(3): 321-341.

ARISTOTELES (2007). "De Memoria et Reminiscentia," Aristotle on Memory and Recollection: Text, Translation, Interpretation, and Reception in Western Scholasticism, trans. \& ed. David Bloch, Leiden; Boston: Brill Publishing.

BANICH, Marie T. (2009). "Executive Function: The Search for an Integrated Account", Current Directions in Psychological Science, 18(2): 89-94.

BERNECKER, Sven \& Kourken MICHAELIAN (eds.) (2017). The Routledge Handbook of Philosophy of Memory. London: Routledge.

BOWER, Gordon H.; MONTEIRO, Kenneth P.; Stephen G. GILLIGAN (1978). "Emotional Mood as a Context for Learning and Recall", Journal of Verbal Learning and Verbal Behavior, 17(5): 573-585.

FODOR, Jerry A. (1975). The Language of Thought, Cambridge, Mass: Harvard University Press.

FODOR, Jerry A. \& Zenon W. PYLYSHYN (1988). "Connectionism and Cognitive Architecture", Cognition, 28(1-2): 3-71.

GLENBERG, Arthur M. (1997). "What Memory is for", Behavioral and Brain Sciences, 20(1): 1-19.

GODDEN, Duncan R. \& Alan D. BADDELEY (1975). "Context-dependent Memory in Two Natural Environments: On Land and Underwater", British Journal of Psychology, 66(3): 325-331.

GOODWIN, Donald W., et al. (1969). “Alcohol and Recall: State-dependent Effects in Man”, Science, 163(3873): 1358-1360.

HERNANDEZ, Arturo E. \& Iliana REYES (2002). "Within-and BetweenLanguage Priming Differ: Evidence from Repetition of Pictures in Spanish-English Bilinguals", Journal of Experimental Psychology: Learning, Memory, and Cognition, 28.4: 726.

KALISH, D.; MONTAGUE, R. \& G. MAR, (1992). Logic: Techniques of Formal Reasoning, London: Oxford University Press.

LOCKE, John (2017). İnsan Anliğl Üzerine Bir Deneme, çev. Vehbi Hacıkadiroğlu, İstanbul, Kabalcı Yayınevi. 
MALCOLM, Norman (1970) "Memory and Representation,” Noûs, 4(1): 59-70.

MARIAN, Viorica \& Ulric NEISSER (2000). "Language-dependent Recall of Autobiographical Memories", Journal of Experimental Psychology: General, 129(3): 361.

MICHELIAN, Kourken \& John SUTTON (2017). "Memory”, Erişim Tarihi: 15.12.2018, (https://plato.stanford.edu/entries/memory/).

PLATON (2009). Devlet, çev. Sebahatttin Eyüpoğlu \& M. Ali Cimcoz. Ankara: Türkiye İş Bankası Kültür Yayınları.

PLATON (2009). Devlet, çev. Sebahatttin Eyüpoğlu \& M. Ali Cimcoz. Ankara: Türkiye İş Bankası Kültür Yayınları.

PLATON (2012). Phaidon, çev. Nazile Kalaycı. İstanbul: Kabalcı Yayınevi.

PLATON (2014). Theaitetos, çev. Furkan Akderin. İstanbul: Say Yayınları.

RUSSELL, Bertrand (1911/1994). Felsefe Sorunları, çev. Vehbi Hacıkadiroğlu, İstanbul: Kabalcı Yayınevi.

SMITH, Steven M. \& Edward VELA (2001). "Environmental Contextdependent Memory: A Review and Meta-analysis", Psychonomic Bulletin \& Review, 8(2): 203-220.

TRAVIS, Catherine E.; CACOULLOS, TORRES, Rena; Evan KIDD (2017). "Cross-language Priming: A View from Bilingual Speech", Bilingualism: Language and Cognition, 20(2): 283-298.

TULVING, Endel \& Donald M. THOMSON (1973). "Encoding Specificity and Retrieval Processes in Episodic Memory”, Psychological Review, 80(5): 352. 